\title{
アメリカにおけるSHPPSの展開
}

\author{
山崎 秀夫
}

\section{Development of school health policies and programs study in the United States of America}

\author{
Hideo Yamazaki
}

\begin{abstract}
The main purpose of this paper is to describe the research background, purpose, framework, contents, and methods of the School Health Policies and Programs Study (SHPPS) developed in the United States of America. SHPPS was the study of school health in the USA carried out by the Centers for Disease Control and Prevention (CDC) in 1994 (SHPPS1994) and 2000 (SHPPS2000). The components of SHPPS1994 were five elements: school health education, physical education, health services, food services, and health policies prohibiting the use of tobacco, alcohol and other drugs, and violence. In SHPPS2000, there were eight components: school health education, physical education and activity, health services, mental health and social services, food services, school policy and environment, faculty and staff health promotion, and family and community involvement. SHPPS1994 and SHPPS2000 assessed the nationwide status of policies and programs for school health in the USA. Specifically, SHPPS1994 was the first study to examine multiple components of the school health program at the state, district, and school levels from comprehensive and multidimensional standpoints. Today's American youth have faced many public health, educational, and social problems not experienced by previous generations of young people. These problems have included violence, drug abuse, sexually transmitted diseases, unintended pregnancy, school dropout, low literacy, and disrupted family and home situations. The primary cause of these phenomena appears to be unconformity of their health and education systems. However, it may be more appropriate to recognize this as a problem of all segments of society. By understanding the development of SHPPS, it should be possible to promote school health and health education research. Furthermore, SHPPS should stimulate research into how to foster the adoption and maintenance of school health programs that can have a positive impact on the health status of young people in the USA. SHPPS should also provide some important points for the development of evidence-based school health policies and programs or health education in Japan.
\end{abstract}

Key words : school health study, health education, organized research system, followup study, scientific evidence

(Japan J. Phys. Educ. Hlth. Sport Sci. 48: 511-522, September, 2003)

東海大学体育学部

₹ 259-1292 神奈川県平塚市北金目 1117

連絡先 山崎秀夫
School of Physical Education, Tokai University

1117 Kitakaname, Hiratsuka-shi, Kanagawa 259-1292

Correspondingauthor mounttop@keyaki.cc.u-tokai.ac.jp 
キーワード：学校保健研究, 保健教育, 組織的調 查研究, 追跡研究, 科学的根拠

\section{I はじめに}

本論文で扱う SHPPS（School Health Policies and Programs Study) は, CDC (The Centers for Disease Control and Prevention）が母体とな り，1994 年及び 2000 年にアメリカで実施された 学校保健政策・学校保健プログラムに関する調査 研究を指している. SHPPS（以下，日本語表記 する場合は「シュップス」と記す）は，アメリカ の州・地方・学校・学級の各単位における学校保 健を新しい視点から捉え追究した研究である。 1994 年に実施された最初のシュップスを SHPPS1994，2000年に行われた 2 回目のシュッ プスを SHPPS2000 と呼んでいる. SHPPS1994は, 学校における保健教育 (health education), 体育 (physical education), 学校保健サービス (health services), 学校給食サービス (food service), 喫煙・飲酒と薬物使用・暴力防止のた めの保健政策 (health policies prohibiting tobacco use, alcohol and other drug use, and violence) の 5つの領域から成り立っている（Kann et al., 1995)。SHPPS2000では，保健教育（health education)，体育・身体活動 (physical education and activity), 学校保健サービス（health services), 精神保健・社会サービス（mental health and social services), 学校給食サービス (food service), 学校政策·学校環境 (school policy and environment), 教職員の健康增進 (faculty and staff health promotion), 家庭 - 地域社会連 携 (family and community involvement) の8 領 域がその構成要素となっている（Kolbe et al., 2001).このような包括的・多元的な学校保健の 調查研究を，全米規模で多層的に展開したのは類 例のないことであった。

シュップスの背景には，アメリカの青少年がかつ て経験したこともないような公衆衛生学的・教育 的・社会的な難問に直面しているという現実があ った。暴力, 薬物の濫用, HIV 感染・STD, 望
まない妊娠, 学校からのドロップアウト, 基礎学 力の低下, 家庭の崩壊, 等の問題が深刻化し, 単 に教育や学校という枠では括れない拡がりを呈し てきていることに対する危機感の現れでもあった (Satcher, 1995).このような現象を醉し出した 主因として，健康や教育のシステムの不適合性を 指摘することができる，しかし，それは健康ある いは教育という単独・個別システムの問題ではな く，青少年を包み込む社会全体としてのシステム の問題として受け止めるのが適切であろう。その ような問題を解決するためには, 閉ざされたシス テム・空間の範囲内で, 学校あるいは教師等が単 独に最善策を講ずるだけでは不十分で，社会をあ げて取り組む必要がある。しかも，問題解決に向 けて，表出する個別の問題に対する特異的対応の みならず，他の関連問題も含めた共通的・根本的 対応が求められる，それは，青少年の心身状態の 動的水準を高める対策を講ずることに帰着する。 そのためには，シュップスにみられるような包括 的な要素が良好に機能することや，空間的な境界 に囚われない活動が求められる.

ほぼすべての青少年が係わる施設である学校に おける学校保健プログラムは, 青少年に直接的に 働きかけ，健康関連行動を改善させたり，そのパ フォーマンスを向上させたりする上で, 重要な役 割を演じ得る。さらに，現在のみならず青少年の 将来の健康をも左右する認識や技術等を修得する 機会も与える.シュップスは青少年の健康の現在 軸（cross-sectional aspect）を扱ったものである が，SHPPS1994から SHPPS2000への展開にみら れるような経時軸（longitudinal aspect）をも視 野に入れた壮大な構想の基に計画されている。 シ ュップスはアメリカに打ける国策としての Healthy People 2000 (US Dept of Health and Human Services, 1991) 及び Healthy People 2010 (US Dept of Health and Human Services, 2000）やCDCによる大規模な断面的研究（repeated cross-sectional study) であるYRBSS (Youth Risk Behavior Surveillance System) (Kann et al., 1995 ; Kann et al., 2000) 等との 関連・調整を巧みに図りながら展開されている。 
我が国においては，文部科学省の「学校保健統計 調査」「学校基本調査」「体力 - 運動能力調查」, 厚生労働省の「国民栄養調查」「国民生活基礎調 査」「患者調查」，（財）日本学校保健会の「保健 室利用状況に関する調査」, 警察庁の「交通統計」, 日本体育・学校健康センターの学校安全・災害共 済給付に関する調查等，学校保健・保健教育に関 係する全国規模の統計調査が実施され，また，学 術的立場から個人あるいはチームによる単発的な 調查も実施されている。しかし，我が国の場合， シュップスのように母体となる中核機関を常設さ せ，主要関連機関との協力体制を確立しながら， 青少年の健康課題解決に向けて戦略的に取り組ん でいる研究例はみられない（なお，シュップスの 詳細については後述する)。我が国の青少年の健 康を考え対策を講ずる上でも，学校保健あるいは 保健教育の現状を分析し将来展望を描く上でも, アメリカにおけるシュップスの展開は貴重な示唆 を与え得るものと思われる。

\section{II シュップスに影響を与えた SHESの展開}

CDC はSHPPS1994の研究報告書の序文で, SHES (School Health Education Study) の重要 性について特筆し，次のように述べている (CDC, 1995).

「30年以上にわたり学校保健政策・学校保健プ ログラムの拠り所となったSHESに感謝の意を表 わし SHPPS 報告書を献呈する」

これは，アメリカに扔ける保健教育や学校保健 の展開に果たしたSHESの役割や重要性を評価す るとともに，SHESの精神を引き継ぐプログラム としてシュップスを位置付けていることを示唆し ている. SHESは1960年代にアメリカにおいて 展開された保健教育教材に関する研究及びその成 果を指しており，次のような 3 段階の研究過程を 経て実施された（SHES，1967）。

1）第 1 段階：保健教育の実施状況調査と先行 研究の集的

アメリカの公立学校における保健教育の実施状
況を全米規模で調査し，保健教育の授業実施の有 無，担当者，対象者，教材等，保健に関する教育 内容や教育方法についての実態を，科学的手続き にしたがい明らかにした。同時に，保健教育に関 わる先行研究の整理が行われデータベース化が試 みられた。

2）第 2 段階：実験カリキュラムの構築とその 修正

保健教育に関する実態調查の結果と徹底した先 行研究の整理を踏まえて，保健教育の新しいカリ キュラムの理論構築が検討され実験カリキュラム が構成された。その実験カリキュラムに対して， 医学・保健・教育等の関連領域の専門家からの意 見を反映させ，多角的な観点から修正が試みられ 最終的な実験カリキュラムが提示された。

3）第 3 段階：実験学校における授業展開とそ の修正

保健教育の実験カリキュラムを導入した学校が 多数指定され，実験的授業が展開された。この実 験学校における授業の結果に基ついて専門家によ る検討が加えられ，カリキュラム修正が行われな がら実験カリキュラムが改善されていった。

このカリキュラムに則り編集された保健教科書 が広く採用され，その後のアメリカにおける保健 教育の展開に多大な影響を及ぼした。このような プロジェクト研究の成果は, 我が国の保健教育に も強いインパクトを与えるものとなった。

SHESのカリキュラムは概念を基盤として成り 立っており，次のように階層的に構造化されてい ることが特徵である。

1) Key Concepts

健康の獲得・維持・増進を左右する基礎となる 大概念で，意思決定，相互作用，発育・発達の 3 つの概念が含まれる。

2) Concepts

保健教育の領域を構成する要素となる中概念で 10 の概念が含まれる。これはカリキュラムの構 成要素と受け取ることができる概念で，単にテー マを設定したものではなく学習の結果として期待 されることを示すものである.

3) Sub concepts 
10 の中概念を具体化させる形で 32 の小概念が 含まれる。これは保健教育の内容を規定する要素 として設定されている．さらに，各々にLong Range Goals が設定され，概念同士の関係といえ る「横糸」と $\mathrm{K}$ - 12 学年までの学習の関係を表 わす「縦系」が巧みに編み込まれた構造が提示さ れている.

主に保健教育研究でSHESが示した独自的な着 眼・方法論は, シュップスの構想に甚大な影響を 与えたことに異論はない。ただし, SHESの研究 母体が，研究組織的・予算的にも継続的研究遂行 性の観点からみて十分でなかったことはSHESに とって不幸といわざるを得なかったが, 結果とし てシュップスの動機のひとつとして活かされその 礎となることになった。

\section{SHPPS1994の展開}

SHESの影響力はアメリカにとどまらず我が国 にも及ぶ程甚大なものであったが，1994年に SHESを見直す形でシュップスが展開されること になる。これは，SHESに代わるというより， SHESを現代化の視点から捉え直したと受け取る のが適切であると思われる.シュップスはCDC が研究母体となり開発したプログラムで，SHES 後約 30 年を経た時点での青少年をめぐる健康の 現状認識と現代的な健康関連ニーズへの対応に応 える立場から展開されたものである.このことは， SHPPS1994の研究報告書において「現状を知る ことにより，これからどこへ向かうべきなのか， 何をすべきなのか，を決定することができる」 （Kann et al., 1995）とその動機を述べているこ とからも推察できる.

\section{SHPPS1994の背景}

$\mathrm{CDC}$ は，アメリカの青少年をめぐる死亡・傷 病・社会問題の多くは, 車輌事故（対全死亡 $30 \%$ ，他の不慮の事故（同 $12 \%$ ，殺人（同 $19 \%$ )，自殺（同 $11 \%$ ）等，予防可能な問題であ ると分析している（Hoffereth，1987；CDC, 1991 ; Perrine et al., 1988 ; Fullilove et al.,
1990 ; Kochanek and Hudson, 1995).さらに, 国民の死亡・疾病の主要な原因と深く関わる行動 要素として, 安全ベルトの未装着や火器携行のよ うな不慮・過失的傷害に結びつく行動, 契煙, 飲 酒・薬物の使用, 望まない妊娠・STD（HIV 感 染を含む）に結びつく性行動, 不健康な食行動, 身体活動の不活発さ，という $6 つ の$ 行動を抽出し， このような行動が少年期に確立され青年期に拡大 されることや相互に関連性を持つこと, 健康状態 のみならず教育的・経済的にも重要な影響を及ぼ すこと，等を指摘している（Kann et al., 1993 ; Kann et al., 1995). そして, 学校が青少年の生 活に及ほす影響の重大性を踏まえ（National Center for Education Statistics, 1993 ; National Education Commission on Time and Learning, 1994）, 学校保健プログラムの展開が, 健康危険 行動やそれに起因する問題を防止するための効果 的な手段であることを強調しながら，伝統的な学 校保健プログラムの内容として保健教育（health education), 学校保健サービス (health services), 学校保健環境 (health environment) の3つの領 域構成をとる立場があることを指摘した上で，現 代的な視点から包括的学校保健プログラムの内容 を捉え，次の相互に関連し合う8つの領域をその 内容とする立場を示している（Allensworth and Kolbe, 1987).

（1）保健教育（health education）

（2）体育と他の身体活動（physical education and other physical activities)

（3）学校保健サービス（health services）

（4）学校給食サービス (food services)

(5) 学校カウンセリングと社会サービス (school counseling and social services)

（6）学校と地域社会の連携・協力（integrated school and community efforts)

（7）教職員の健康增進（faculty and staff health promotion)

（8）学校環境 (school environment)

また，学校保健プログラム内容に影響を及ほし た主な見解や組織の活動を整理し（CDC， 1988 ; Seffrin, 1990 ; CDC, 1994 ; US Dept of 
Agriculture, 1994 ; Riley and Shalala, 1994 ; Allensworth et al., 1995), 学校保健プログラム の現状に関する情報を ASHA 等多様な情報資源 から収集している（Lovato et al., 1989 ; Ross and Gilbert, 1985 ; Ross and Pate, 1987 ; National Association of State Boards of Education and Council of Chief State School Officers, 1991 ; Holtzman et al., 1992 ; Burghardt and Devaney, 1993).

このように，科学的研究結果に基づきながら最 新データへの更新を行う等, シュップス開発へ向 けて合理的な手続きが展開されている。ただし， CDCは，それぞれの先行研究が重要な情報を提 供している一方で, 全国規模での学校保健プログ ラムの包括的評価が行われていないことを鋭く指 摘し，シュップスの意義を強調している。このよ うな問題認識は, 我が国における学校保健・保健 教育の研究展開を考える上で重要な示唆を与えて くれる。

\section{SHPPS1994の目的}

SHPPS1994 は学校保健プログラムの構成要素 を多元的に捉え, 州・地方・学校・学級の各単位 における政策・内容を評価するために設計されて いる. 特に, 州・地方・学校・学級の各単位にお ける学校保健プログラムの 5 つの構成領域（保健 教育, 体育, 学校保健サービス, 学校給食サービ ス, 契煙 - 飲酒 ·薬物使用 $\cdot$ 暴力 $\cdot \mathrm{HIV}$ 感染予 防・防止の保健政策) の全国規模の現状はどうな のか, 学校保健プログラムの各領域を遂行する責 任者は誰なのか, 各領域間にどのような協力体制 があるのか，州・地方の政策と学校プログラム・ サービスとの間にどうのような関連性がみられる のか，学校保健プログラムの遂行を促進・阻害す る要因は何か，等の問題に答えが得られるよう計 画されている。さらに, Healthy People 2000 (Public Health Service，1991）に揭げられた 300 に及ぶ測定可能な目標のうち，青年に関わる 111 目標の中の 14 目標は学校において直接達成され るべきものとして, シュップスにより実態解明さ れるよう企画されている.

\section{SHPPS1994の方法論}

1）質問紙の開発と試行

Healthy People 2000の 14 目標を大まかな枠組 みとし，学校保健プログラムの 5 つの構成領域 （保健教育, 体育, 学校保健サービス, 学校給食 サービス，喫煙・飲酒・薬物使用・暴力・HIV 感染予防・防止の保健政策）を含んだ質問紙が 1992年 9 月から開発された。加えて，国・州・地 方単位で調查された学校保健プログラムの構成要 素が収集・検討された。その結果，The National Children and Youth Fitness Studies I and II, The School Nutrition Dietary Assessment Study のような全国規模調查は調查内容として SHPPS1994の学校保健プログラムの構成領域を 一つしか含んでいないこと, 州単位でみても SHPPS1994の学校保健プログラムの構成領域を 複数扱っている調查の実施例が極めて少ないこ と, 唯一ニューメキシコ州に打ける調査が SHPPS1994の学校保健プログラムの構成領域す べてを含んでいるにすぎないこと，等が明らかに されている。この内容はSHPPS1994の開発過程 で重要な影響を及ぼし，SHPPS1994の初期の項 目群に反映されることになる。

1993 年 1 月に, SHPPS1994の 5 つの構成領域 について検討を加えるため，各領域の専門家によ る研究会が開催され，まず測定尺度や質問項目が 選定されている，さらに，専門家と学識経験者か らなる拡大研究会が開催され，質問項目の精選 • 表現・質問順序等について検討が加えられた後, 専門組織（国）・専門機関（州・地方）・連邦機 関・現場スタッフ等による広範な吟味や何段階も のテスト・改訂が行われている。最終的に約 15ケ月の期間を費やし SHPPS1994 調查票が提示 されている(表1).

2) PSU (Primary Sampling Unit) の設定と標 本抽出

SHPPS1994では，全米が3,104のPSU（Primary Sampling Unit）に分割され，さらに都市層 282PSU ・非都市層 2,822PSUに層化識別された 後, 次のような手順で調查対象が設定されている。

(1)州単位：すべての州（50州とワシントン, 
D.C.）を対象とした悉皆調査であるため標本抽出 は行われていない。

(2)地方単位：95\%信頼区間（誤差 $\pm 5 \%$ ）の 精度で全国推計できるよう設計され，非回答率を $20 \%$ と推定した上で 480PSUが系統的（等間隔） 無作為抽出されている。この 480PSUには全 13,169地方の内 4,105地方が含まれ，それに基づ き調查地方選定のための抽出枠が構成されてい る、ここから，第1段階として抽出された 652 地
方について，基準との照合手続きを行い最終的に 502 地方が調查対象となっている.

(3)学校単位: 調查対象学校は対象地方から抽出 されること，国の健康目標（K-12学年までの 保健教育を計画的・継続的に行う一貫教育を採用 する学校の割合を少なくとも $75 \%$ にまで高める） の測定を行う必要性があること，非回答率の推定 が $20 \%$ であこと，等の条件を加味し， $95 \%$ 信 頼区間（誤差 $\pm 5 \% ）$ の精度で推計できるための

表 1 SHPPS 1994 調査票の概要

\begin{tabular}{|c|c|c|c|c|c|}
\hline \multicolumn{2}{|c|}{ 調查単位·領域 } & 目的 & 回答者 & $\begin{array}{l}\text { 学校· } \\
\text { 学年範囲 }\end{array}$ & $\begin{array}{l}\overrightarrow{テ ゙} ー \text { 夕 } \\
\text { 収集法 }\end{array}$ \\
\hline \multirow{5}{*}{$\begin{array}{l}\text { 州 } \\
\text { 単 } \\
\text { 位 }\end{array}$} & 保健教育 & $\begin{array}{l}\text { 州単位の保健教育方針· } \\
\text { 計画を探る }\end{array}$ & 州単位の保健教育責任者 & $\mathrm{K}-12$ & 郵送 \\
\hline & 体育 & $\begin{array}{l}\text { 州単位の体育方針·計画 } \\
\text { を探る }\end{array}$ & 州単位の体育責任者 & $\mathrm{K}-12$ & 郵送 \\
\hline & 保健サービス & $\begin{array}{l}\text { 州単位の学校保健サー } \\
\text { ビス方針・計画を探る }\end{array}$ & $\begin{array}{l}\text { 州単位の学校保健サービ } \\
\text { ス責任者 }\end{array}$ & $\mathrm{K}-12$ & 郵送 \\
\hline & 給食サービス & $\begin{array}{l}\text { 州単位の学校給食サー } \\
\text { ビス方針・計画を探る }\end{array}$ & $\begin{array}{l}\text { 州単位の学校給食サービ } \\
\text { ス責任者 }\end{array}$ & $\mathrm{K}-12$ & 郵送 \\
\hline & 保健政策 & $\begin{array}{l}\text { 州単位の契煙・AOD 使 } \\
\text { 用·暴力感染に } \\
\text { 関する政策を探る }\end{array}$ & $\begin{array}{l}\text { 州単位の喫煙・AOD 使 } \\
\text { 用・暴力 } \cdot \text { HIV 感染に対 } \\
\text { する政策責任者 }\end{array}$ & $\mathrm{K}-12$ & 郵送 \\
\hline \multirow{5}{*}{$\begin{array}{l}\text { 地 } \\
\text { 穊 } \\
\text { 位 }\end{array}$} & 保健教育 & $\begin{array}{l}\text { 地方単位の保健教育方 } \\
\text { 針・計画を探る }\end{array}$ & $\begin{array}{l}\text { 地方単位の保健教育責任 } \\
\text { 者 }\end{array}$ & $\mathrm{K}-12$ & 郵送 \\
\hline & 体育 & $\begin{array}{l}\text { 地方単位の体育方針·計 } \\
\text { 画を探る }\end{array}$ & 地方単位の体育責任者 & $\mathrm{K}-12$ & 郵送 \\
\hline & 保健サービス & $\begin{array}{l}\text { 地方単位の学校保健 } \\
\text { サービス方針·計画を探 } \\
\text { る }\end{array}$ & $\begin{array}{l}\text { 地方単位の学校保健サー } \\
\text { ビス責任者 }\end{array}$ & $\mathrm{K}-12$ & 郵送 \\
\hline & 給食サービス & $\begin{array}{l}\text { 地方単位の学校給食 } \\
\text { サービス方針·計画を探 } \\
\text { る }\end{array}$ & $\begin{array}{l}\text { 地方単位の学校給食サー } \\
\text { ビス責任者 }\end{array}$ & $\mathrm{K}-12$ & 郵送 \\
\hline & 保健政策 & $\begin{array}{l}\text { 地方単位の喫煙・AOD } \\
\text { 使用・暴力·HIV 感染 } \\
\text { に関する政策を探る }\end{array}$ & $\begin{array}{l}\text { 地方単位の喫煙·AOD使 } \\
\text { 用・暴力・HI染に対 } \\
\text { する政策責任者 }\end{array}$ & $\mathrm{K}-12$ & 郵送 \\
\hline \multirow{5}{*}{$\begin{array}{l}\text { 学 } \\
\text { 篮 } \\
\text { 位 }\end{array}$} & 保健教育 & $\begin{array}{l}\text { 保健教育内容と関連内 } \\
\text { 容を探る }\end{array}$ & $\begin{array}{l}\text { 学校単位の保健教育担当 } \\
\text { 者・責任者 }\end{array}$ & 中・高校 & 面接 \\
\hline & 体育 & $\begin{array}{l}\text { 体育内容と関連内容を } \\
\text { 探る }\end{array}$ & $\begin{array}{l}\text { 学校単位の体育担当者· } \\
\text { 責任者 }\end{array}$ & 中・高校 & 面接 \\
\hline & 保健サービス & $\begin{array}{l}\text { 学校保健サービス内容 } \\
\text { と関連内容を探る }\end{array}$ & $\begin{array}{l}\text { 学校単位の学校保健サー } \\
\text { ビス活動責任者 }\end{array}$ & 中・高校 & 面接 \\
\hline & 給食サービス & $\begin{array}{l}\text { 学校給食サービス内容 } \\
\text { と関連内容を探る }\end{array}$ & $\begin{array}{l}\text { 地方・学校単位の学校給 } \\
\text { 食サービス活動責者 }\end{array}$ & 中·高校 & 面接 \\
\hline & 保健活動方針 & $\begin{array}{l}\text { HIV 感染・喫煙・AOD } \\
\text { 使用·暴力に関する展開 } \\
\text { を探る }\end{array}$ & $\begin{array}{l}\text { 学校単位の制煙·AOD使 } \\
\text { 用·暴力・HI染に対 } \\
\text { する展開責任者 }\end{array}$ & 中・高校 & 面接 \\
\hline \multirow{2}{*}{$\begin{array}{l}\text { 学 } \\
\text { 級 } \\
\text { 単 } \\
\text { 位 }\end{array}$} & 保健教育 & 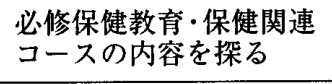 & $\begin{array}{l}\text { 必修保健教育・保健関連 } \\
コ ー ス \text { 担当教師 }\end{array}$ & 中・高校 & 面接 \\
\hline & 体育 & $\begin{array}{l}\text { 必修体育コースの内容 } \\
\text { を探る }\end{array}$ & 必修体育担当教師 & 中・高校 & 面接 \\
\hline
\end{tabular}


抽出規模として中学校 384 校・高校 384 校の計 768 校が設定され，(此例）無作為抽出されてい る.ただし， 2 校が研究上不適格・開設学年なし の理由で除外されたため, 最終学校標本は 766 校 となっている.

(4)学級単位: 調査対象学級は調査対象学校から 抽出され，必修体育コースを教える教師（必修体 育担当体育教師)，主に保健教育トピックスに焦 点を合わせた必修コースを教える教師（必修保健 教育担当保健教育教師), 保健教育卜ピックスを 含むが主たる焦点が他の教科にある必修コースを 教える教師（必修他教科担当保健教育教師），の 3つの教師グループについて全国推計できるよう $95 \%$ 信頼区間（誤差士 $5 \%$ ）の精度で抽出数が設 定され，結果的に体育教師（必修体育担当） 1,314名，保健教育教師（必修保健教育担当） 640 名，保健教育教師（必修他教科担当）1,003名が 調查対象教師として抽出されている.

3）調查方法

(1)州・地方単位の調查は 1994年 3-6月にかけ て郵送法により行われている。州単位・地方単位 とも, SHPPS1994の5つの構成要素各々に責任 を持つ人に調査票が郵送され，その責任者から直 接の担当者に調查票が配布されている。誤記入・ 未記入等があった場合には, 必要に応じて電話や 郵便で追跡が行われている.

(2)学校・学級単位の調査は 1994 年 $2-6$ 月にか けて面接法により行われている。面接は事前に 9 日間集中的な訓練を受けたデー夕収集者が各学 校を訪問し個人面接の形式で行われている.

4) 回収状況

州単位ではすべての州教育機関が回答し（回答 率 $100 \%$ ），地方単位では 502 地方中 413 地方（同 $82 \%$ ), 学校単位では 766 校中 607 校（同 $79 \%$ ) が回答している，学級単位では体育教師 1,314 名 中 921 名, 保健教育教師 1,643 名中 1,040 名が回答 している（回答率は各々 70\%，63\%）。

5）全国推計のための重み付けと推定分散 地方・学校・学級単位のデー夕は, 全国推計を 求めるため重み付けがなされている，全国平均 は, 重み係数（ケース選択の確率，非回答の調整，
階層化後の調整の逆数で構成）と測定值の積の総 和を重み係数の総和で除することにより推定され ている。ささらに，一般線形分散推定法により分散 が推定され，12種の州単位・地方単位・学校単 位・学級単位の調查票それぞれについて，観測率 に応じた標準䛊差が算出されている。

CDC はSHPPS1994の研究報告書の結論におい て, 5つの包括的学校保健要素, 4 つの回答単位,

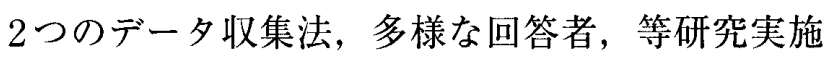
に伴う種々の困難を克服するために参考とすべき 先行研究が皆無であったことを強調し，それに挑 んだ姿勢を「挑戦」と表現している。そして， SHPPS1994の方法論や知見が，将来の研究に向 けて，何をなすのが最善なのか，改善すべきもの は何か，等を決定する際の道標になることを確信 し報告書を結んでいる。このことは，我が国にお ける学校保健 ・保健教育関係の研究推進にとって も有意義な示唆を与え得るし，シュップスの開発 の過程や実施の実際を知ることで，我が国独自の 研究展開のための具体的イメージを抱くこともで きるのではなかろうか.

\section{SHPPS1994 から SHPPS2000へ}

$\mathrm{CDC}$ は 2000 年に 2 回目のシュップスとなる SHPPS2000を実施している.SHPPS2000は，既 述のとおり学校保健プログラムの構成要素とし て, 保健教育, 体育・身体活動, 学校保健开ービ ス, 精神保健・社会サービス, 学校給食サービス, 学校政策 - 学校環境, 教職員の健康増進, 家庭 · 地域社会連携,の8領域をすべて含んだ最初の評 価プログラムである。この 8 領域構成は, 結果と してAllensworth et al.（1987）が提唱した包括 的学校保健プログラムの搪大概念にしたがったも ので, SHPPS1994（CDC，1995）よりさらに包 括的な内容を構成するものとなっている.

\section{SHPPS 2000 の目的}

SHPPS2000 は, 基本的にSHPPS1994の postsurvey 的な研究として位置付けられるが, SHPPS1994では調查しなかった構成領域・学校 
（小学校）を扱っている点や学校基盤型保健セン 夕-（school-based health centers）・学校連携 型保健サービス（school-linked health services） の拡がりを考慮している点等, 独自の特徽も有し ている (Institute of Medicine, 1997). CDCは, 最大規模で完全な学校保健プログラムの評価プロ グラムとしてSHPPS2000を捉えている．その背 景には組織的支援体制の確立・充実があり， American Association for Health Education, American Association of School Administrators, National Association of School Nurses, American School Food Service Association 等, 全米規 模の 19 関連組織間での協力体制が強化されたこ とを強調している。

SHPPS2000は, 具体的に, 学校保健プログラ 厶 8 領域の実践における全国規模 (州・地方・学 校・学級各単位) での特徴は何か, 領域間の調整 者・責任者は誰で，どのような教育・研修を受け ているのか, 各領域担当者の協力体制や州・地方 機関等の担当者との協力体制はどのようになって いるのか, SHPPS1994 以来, 学校保健プログラ ムは変わってきているのか, 等の問題に答えが得 られるよう計画されている。

また，SHPPS2000のデータについては， Healthy People 2010 (US Dept of Health and Human Services, 2000）の7つの関連目標の測 定を行うこと, National Education Goals（National Education Goals Panel, 1994）における関 連内容 (飲酒・薬物使用の解消に向けての学校環 境の整備, 生徒の健康を保障するための体育 ・保 健教育の徹底的実践, 子どもの社会的・情緒的 · 知識的成長を促進するための学校と家庭の連携) を評価すること, 公・私立学校のイニシアティブ を支援すること, 州が学校・地方における技術的 援助・専門的準備・予算配分について決定するの を手助けすること, 親・学校委員・学校管理者・ 教師・地域社会の人たちが, 学校保健政策・プロ グラムを決定するのを手助けすること, 重大な健 康危険行動が，学校保健政策・プログラムにより 回避できることを生徒に理解させること, 等のよ うな活用が期待されている.

\section{SHPPS2000の方法論}

1) SHPPS2000 調査票の開発と試行

SHPPS2000 調査票は, 1997 年 7 月一 1999 年 12 月にかけて開発されている. 調査票の初期の枠組 みは, Healthy People 2000, Healthy People 2010, SHPPS1994 調査票, SHPPS1994 データ, SHPPS2000を構成する 8 領域に関する文献・先 行研究の整理, 等により形作られている. 1998 年1月に, SHPPS1994で扱われなかった内容に ついて, SHPPS専門委員会と学校関係者によっ て詳細な検討がなされ，新要素で測定されるべき 鍵事項についての共通理解が得られている. 1998 年夏には, SHPPS2000 調査票の原案が作成され, 150 を超える国機関・組織に対して調査内容に対 する意見を求めている，最終的に作成された調查 票は, 州・地方版調査票が自記式質問紙形式で, 学校・学級版調査票がコンピュータ入力式インタ ビュー形式（CAPI）のものとなっている.

調查票の質問内容にはSHPPS1994 と同じ項目 やSHPPS1994年以降深刻化した問題等が含まれ， 各項目におけるワーディングや回答に要する時間 等が吟味された後, 学校・地方・州単位の教育機 関関係者（任意協力者）を対象に事前調査が試行 されている．1999年 4 月には，公・私立52校（3 州）を対象に, 体育・身体活動 (学校単位), 学 校保健サービス (学校単位), 精神保健・社会 サービス (学校単位), 保健教育 (学級単位) の 質問紙による準公式調査が試行されている．試行 結果に基づき，回答の信頼性がそしいと判断され た質問項目は修正・削除されている。

2) 標本抽出

(1)州単位：SHPPS1994 と同様, 悉皆調查のた め, 標本抽出は行われていない。

(2)地方単位：基本的にはSHPPS1994 と同様の 手続きを踏んでいる。まず，標本抽出枠 13,999 地 方が決定され，そこから 8,559PSUが構成され， さらに528PSUが抽出されている。最終的には 745 地方が設定されている.

(3)学校単位：抽出枠として 132,114 校が決定さ れ，学校規模・学校種別・設置形態等の条件によ り層化された後，最終的に調査対象として 1,331 
表 2 必修保健教育で扱われるべき内容（SHPPS 1994・SHPPS 2000 の結果）

\begin{tabular}{|c|c|c|c|c|c|c|c|}
\hline \multicolumn{4}{|c|}{ SHPPS $1994^{22}$} & \multicolumn{4}{|c|}{ SHPPS $2000^{22}$} \\
\hline 内容 ${ }^{1)}$ & $\begin{array}{c}\text { 州単位 } \\
(\%)\end{array}$ & $\begin{array}{c}\text { 地方単位 } \\
(\%)\end{array}$ & $\begin{array}{c}\text { 学校単位 } \\
(\%)\end{array}$ & 内容 ${ }^{1)}$ & $\begin{array}{c}\text { 州単位 } \\
(\%)\end{array}$ & $\begin{array}{c}\text { 地方単位 } \\
(\%)\end{array}$ & $\begin{array}{c}\text { 学校単位 } \\
(\%)\end{array}$ \\
\hline AOD 防止 & 75.0 & 86.0 & 90.4 & 事故・傷害防止 & 64.2 & 68.6 & 72.8 \\
\hline 地域保健 & 54.8 & 73.5 & 58.9 & $A O D$ 防止 & 76.5 & 85.1 & 89.1 \\
\hline 葛藤処理 / 暴力防止 & 38.5 & 61.0 & 58.3 & 消費者保健 & 60.2 & 63.8 & 56.1 \\
\hline 消費者保健 & 55.8 & 70.6 & 56.6 & 心肺蘇生 & 31.1 & 43.3 & 35.7 \\
\hline 心肺蘇生 & 37.5 & 61.9 & 48.0 & 死 · 臨死 & 27.5 & 46.8 & 45.8 \\
\hline 死 - 臨死 & 25.0 & 54.1 & 52.5 & 歯· 口腔衛生 & 49.3 & 66.6 & 61.3 \\
\hline 歯· 口腔衛生 & 51.2 & 78.2 & 56.7 & 情緒·精神保健 & 64.5 & 72.5 & 71.0 \\
\hline 食行動・栄養 & 68.9 & 80.1 & 84.3 & 環境保健 & 52.9 & 65.1 & 65.2 \\
\hline 疾病予防・管理 & 68.9 & 81.3 & 84.5 & 救急法 & 52.6 & 57.6 & 54.0 \\
\hline 情緒・精神保健 & 64.4 & 76.8 & 73.8 & 発䏍·発達 & 61.9 & 78.6 & 81.7 \\
\hline 環境保健 & 59.1 & 70.5 & 59.9 & HIV 予防 & 68.7 & 75.7 & 70.5 \\
\hline 救急法 & 55.8 & 73.9 & 58.8 & 性教育 & 45.3 & 66.9 & 71.5 \\
\hline 発育・発達 & 62.2 & 79.5 & 80.2 & 免疫 - 予防接種 & 38.4 & 59.9 & 45.6 \\
\hline HIV 予防 & 78.7 & 83.0 & 85.6 & 栄養·食行動 & 68.6 & 77.7 & 84.6 \\
\hline 性教育 & 48.9 & 76.0 & 80.0 & 個人保健 & 66.0 & 75.2 & 77.4 \\
\hline 傷害防止·安全 & 62.2 & 74.5 & 66.2 & 身体活動・体力 & 61.9 & 72.8 & 76.9 \\
\hline 個人保健 & 63.0 & 81.2 & 79.0 & 避妊 & 39.4 & 53.7 & 51.0 \\
\hline 身体活動・体力 & 65.2 & 81.9 & 77.6 & STD 予防 & 54.9 & 64.9 & 59.5 \\
\hline 避妊 & 43.9 & 72.1 & 69.3 & 紫外線・皮膚癌予防 & 30.0 & 58.9 & 55.4 \\
\hline STD 予防 & 65.1 & 80.9 & 84.1 & 自殺防止 & 38.0 & 53.1 & 49.0 \\
\hline 自殺防止 & 37.8 & 66.7 & 58.1 & 契煙防止 & 75.8 & 84.5 & 87.5 \\
\hline 喫煙防止 & 71.7 & 83.2 & 85.6 & 暴力防止 & 59.2 & 73.2 & 77.4 \\
\hline
\end{tabular}

1) 内容は原語のアルファベット順に掲載

2）表中数值は，必修保健教育で扱われるべき内容として肯定的な反応率（単位毎に【(肯定応答：回答数）×100】 で算出した値)

校が抽出されている。

(4)学級単位：学校単位における調查対象校から CAPI対象の学級が抽出されている．保健教育と 体育の必修コースを設置している学校の中で, 保 健教育のCAPI 対象学級は 1,706 学級, 体育では 1,729学級が対象となっている.

3）回答状況

州単位では 51 州すべてから，地方単位では 745 地方中 560 地方から，学校単位では 1,331 校中 950 校から回答が得られている（回答率は各々 $100 \%$, $75 \%, 71 \%)$ ，学級単位においては，保健教育担 当教師で 1,706 名中 1,534 名から, 体育担当教師で 1,729 名中 1,564 名から回答が得られている（回答 率いずれも $90 \%)$ 。

4) デー夕分析

分散は，SHPPS2000における標本抽出の複雑
性を考慮し，一般線形分散推定法により推定され ている. 16 種の州単位・地方単位・学校単位・ 学級単位の各々の調査票における鍵変数の標準誤 差が算出されている．内容的にはSHPPS1994の 場合と同様なので，SHPPS1994の項を参照して 戴きたい.

\section{V シュップスにおける保健教育領域に 関する調査結果の概略}

シュップスの調査結果について SHPPS1994・ SHPPS2000 両者の結果全容を扱うと膨大な紙幅 を要する，本論文では主にシュップスの枠組み・ 展開の仕組み等について言及することに主眼を置 いている，等を考慮し，ここではSHPPS1994保 健教育及びSHPPS2000 保健教育の調查結果の一 
部を述べるにとどめたい.

シュップスにおいて扱われているトピックス は，アメリカにおける保健教育内容を反映してい ることから，保健教育内容を理解する上で参考に なると思われるので, 調査結果とともにその内容 の一部を示した（表 2)。そこには，保健教育内 容として, SHPPS1994保健教育・SHPPS2000保 健教育ともに 22 項目が示されている.

\section{VI＼cjkstart健康戦略としてのシュップスの展開}

SHPPS2000の設計は基本的にSHPPS1994に基 づいている. しかし，標本対象に小学校を加えた こと, 地方・学校単位の標本数を全体的に増加さ せたこと, 学校保健プログラムの内容を 8 領域構 成としたこと，学校・学級単位のデー夕収集をよ $り$ 精度の高いCAPIを採用して行ったこと, 等 SHPPS1994を大幅に改善した研究になっている.

シュップスは, アメリカに㧍ける青少年の健康 を cross-sectional aspect と longitudinal aspect 両視点から捉え, 計画性のある分析を通して将来 の政策的基本構想軸を設定するための基礎研究と して位置付けられている，そのため，次のような 課題について検討が加えられている.

1）シュップスの定期的実施：シュップスを一 定の周期で実施するための条件整備（研究 組織の充実化・研究予算の安定化・協力体 制の拡充化等）を図ること.

2）シュップスの実施周期の検討：SHPPS1994 から SHPPS2000までの実施間隔は 6 年であ ったが, 周期として適切な間隔を探り出す こと. 加えて, 青少年の健康問題の質的 量的の状態 (悪化・加速化等)により周期 を見直すこと．

3）シュップスの標本抽出法の吟味：地方単 位・学校単位・学級単位の標本抽出方法を 再検討し抽出誤差を減じて推定精度を高め ること.

4）シュップスのデータ収集法の検討：州単 位・地方単位で採用されている自記式質問 紙法, 学校単位・学級単位で採用されてい
る個別面接法あるいはCAPIについて検討 を加えること．具体的に，電話調査法やイ ンターネット調查法の導入の可能性や効率 性（費用対効果等）を検討すること.

5）学校保健プログラムの構成領域の検討： SHPPS1994では 5 領域, SHPPS2000におい ては 8 領域構成であったが, 青少年をめぐ る健康問題の変化への対応等のため見直す 必要があること．ただし，基本的（普遍的） な領域構成の原則は常に視野に入れておく こと.

6）関連調查研究との連携・調整：国の健康戦 略としての Healthy People 2000 - Healthy People 2010 との連携を強化するとともに, それらとシュップスとの調査的重複を避け 相互のデータの効率的活用を可能にするこ

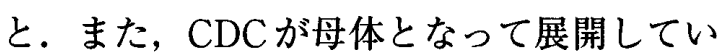

るYRBSS との調整を図ること。

以上のような取り組みは，アメリカにおける青 少年の健康問題に対して，現状を直視し課題解決 へ積極的に対応しようとするアメリカの姿勢の現 われでもあり，その戦略の根幹にシュップスが位 置付けられることが示唆されている.

\section{VII 根拠に基づく学校保健・ 保健教育への示唆}

欧米の医学で重視されている根拠に基づく医療 (evidence-based medicine) の流れは，我が国の 医学領域にも影響を及ぼし，経験主義的な知見 (偏見)，根拠不明暸な民間療法，無益（有害）な 健康食品などの流布に歯止めをかける状況を䤑し 出している．根拠とは科学に基づく証拠を指すこ とから，根拠に基づく医療は医療の臨床効果と科 学性を最重視する立場に立つことを意味する（た だし，その背景に徹底した効率性・経済性追求の 側面も内包されることは考慮しておくべきであ る).アメリカでは, 疫学的・実験的な研究設計 に基づく科学的手続きを踏まえた上で，科学的証 拠を示す根拠の水準を臨床疫学及び臨床試験の立 場から四段三相に分類している.前者の立場から， 
レベル I（無作為化比較試験による），レベル II (非無作為化比較試験・準実験的研究による)，レ ベル III (非実験的記述研究による)，レベル $\mathrm{V}$ (専門化委員会の意見・権威者の臨床試験による) まで四段階に分類されている.後者の立場からは， 健康人対象で安全性の検証に主眼を置く第一相, 患者対象で主に有効性と用法・用量を検証する第 二相, 多数の患者対象で効果・副作用等を検証す る第三相と，三種類に区別されている，それは， 政策レベルでも同様で，根拠に基づく健康政策 (evidence-based health policy) の重要性が認識 されてきているところでもある。このような科学 的手続きやそれに基づく根拠の扱いは，医学領域 においてのみ必要とされるわけではなく，学校保 健・保健教育領域においても重要な要件となるこ とは否めない，学校保健・保健教育領域における 適切な根拠を探求し設定できるような取り組みが 希求される。このような視点から，アメリカにお けるシュップスの展開を捉え, 科学的根拠の合理 的探求の過程について理解を深める必要性がある と思われる.

アメリカと我が国では青少年を取り巻く健康問 題・課題は質的にも量的にも同じとは限らない。 何より根底に流れる国民性や文化も異なってい る。アメリカには我が国では理解し難い民族性も 存在する．しかし，健康をめぐる問題の本質や根 底では共通する要素も存在するものと思われる。 第 2 次大戦後, 我が国の生活様式や精神性等は急 速にアメリカ化されてきているといわれる．国民 や青少年をめぐる健康問題もアメリカ化の傾向に あることは否めない。ある意味で先行するアメリ 力を理解することにより，我が国が被るかもしれ ない健康被害を未然に防ぐことも可能になるもの と考える，我が国でも，厚生労働省がアメリカに おける Healthy People 2000 の政策的成功を評価 し, Healthy People 2000 を参考にした国民的健

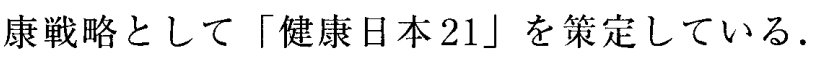
今後我が国においても,「健康日本 $21 」 と$ 学校保 健 ·保健教育との連携のように, 厚生労働省・文 部科学省等という管轄省庁の枠を超えた研究組織 あるいは学術団体・民間研究機関等との連携・調
整が健康戦略を展開する上でより重要になろう。

シュップスに対する理解を深めその展開を参考 にすることが, 我が国の学校保健・保健教育のさ らなる発展に資することを確信している.さらに， シュップス的な手続きを踏むことにより，我が国 の実態に則した学校保健・保健教育の evidencebased policies and programs の設計が可能にな り, 効果的な展開が期待できるものと考える.

\section{文献}

Allensworth, D.D. and Kolbe, L.J. (1987) The comprehensive school health programs: Exploring an expanded concept. J Sch Health 57 (10): 409-412.

Allensworth, D.D., Wyche, J., Lawson, E., and Nicholson, L. (1995) Defining a Comprehensive School Health Program: An Interim Statement. National Academy Press: 2.

Burghardt, J. and Devaney, B. (1993) The School Nutrition Dietary Assessment Study: Summary of Findings. US Dept of Agriculture.

CDC (1988) Guidelines for effective school health education to prevent the spread of AIDS. MMWR 37 (suppl 2): 1-14.

CDC (1991) Division of STD/HIV Prevention Annual Report, 1990. Public Health Services.

CDC (1994) Guidelines for school health programs to prevent tobacco use and addiction. MMWR 43 (RR-2): 1-17.

CDC (1995) School Health Policies and Programs Study: a summary report. J Sch Health 65 (8): 289353.

Fullilove, R.E., Fullilove, M.T., Bowser, B.P., and Gross, S.A. (1990) Risk of sexually transmitted disease among black adolescent crack users in Oakland and San Francisco, California. JAMA 263: 851-855.

Hoffereth, S.L. (1987) Risking the Future: Adolescent Sexuality, Pregnancy, and Childbearing. National Academy Press: 174-206.

Holtzman, D., Greene, B.Z., Ingraham, G.C., Daily, L.A., and Demchuck, D.G. (1992) HIV education and health education in the United States: A national survey of local school district policies and practices. J Sch Health 62 (9): 421-427.

Institute of Medicine (1997) School and Health: Our 
Nation's Investment. Institute of Medicine, National Academy Press (Washington, DC).

Kann, L., Kolbe, L.J., and Collins, J.L. (1993) Measuring the health behavior of adolescents: The Youth Risk Behavior Surveillance System and recent reports on high-risk adolescents. Public Health Rep. 108 (suppl-1): 1-67.

Kann, L., Collins, J.L., Pateman, B.C., Small, M.L., Ross, J.G., and Kolbe, L.J. (1995) The School Health Policies and Programs Study (SHPPS): Rationale for a Nationwide Status Report on School Health Programs. J Sch Health 65 (8): 291-301.

Kann, L., Warren, C.W., Harris, W.A., Collins, J.L., Douglas, K.A., Collins, M.E., Williams, B.I., Ross, J.G., and Kolbe, L.J. (1995) Youth Risk Behavior Surveillance-United States, 1993. J Sch Health 65 (5): 163-171.

Kann, L., Warren C.W., Harris, W.A., Collins, J.L., and Douglas, K.A. (1995) Youth risk behavior surveillance-United States, 1993. MMWR 44 (SS-1): 156.

Kann, L., Kinchen, S.A., Williams, B.I., Ross, J.G., Lowry, R., Grunbaum, J.A. Kolbe, L.J. and State and Local YRBSS Coodinators. (2000) Youth Risk Behavior Surveillance - United States, 1999. J Sch Health 65 (5): 271-285.

Kochanek, K.D. and Hudson, B.L. (1995) Advance report of final mortality statistics, 1992. Mon Vital Statistics Rep. 43 (6-S): 1-74.

Kolbe, L.J., Kann, L., and Brener, N.D. (2001) Overview and Summary of Findings: School Health Policies and Programs Study 2000. J Sch Health 71 (7): 253-259.

Lovato, C.Y., Allensworth, D.D., and Chan, F.A. (1989) School Health in America: An Assessment of State Policies to Protect and Improve the Health of Students, 5th ed. American School Health Association.

National Association of State Boards of Education and Council of Chief State School Officers (1991) AIDS, HIV, and School Health Education: State Policies and Programs 1990. National Association of State Boards of Education the Council of Chief State School Officers.

National Center for Education Statistics (1993) Digest of Education Statistics, 1993, 1993. Office of Education Research and Improvement.
National Education Commission on Time and Learning (1994) Prisoners of Time, 1994. National Education Commission on Time and Learning.

National Education Goals Panel (1994) The National Education Goals Report: Building a Nation of Learners. US Dept of Education (Washington, DC).

Perrine, M., Peck, R., and Fell, J. (1988) Surgeon General's Workshop on Drunk Driving: Background Papers. Office of the Surgeon General 35-76.

Public Health Service (1991) Healthy People 2000: National Health Promotion and Disease Prevention Objectives - Full Report, with Commentary. US Dept of Health and Human Services. 91-50212.

Riley, R.W. and Shalala, D.E. (1994) Joint Statement on school health by the Secretaries of Education and Health and Human Services. April 7.

Ross, J.G. and Gilbert, G.G. (1985) National Children and Youth Fitness Study: A summary of findings. JOPERD 56 (1): 45-50.

Ross, J.G. and Pate, R.R. (1987) National Children and Youth Fitness Study II: A summary of findings. JOPERD 58: 50-96.

Satcher, D. (1995) Foreword: The School Health Policies and Programs Study. J Sch Health 65 (8): 289.

Seffrin, J.R. (1990) The comprehensive school health curriculum: Closing the gap between state-of-theart and state-of-the-practice. J Sch Health 60 (4): 151-156.

SHES (1967) Health Education - A Conceptual Approach to Curriculum Design.

U.S. Dept of Agriculture (1994) USDA Team Nutrition: Strategic Plan for Training and Technical Assistance to Achieve Healthy School Meals. Executive Summary.

US Dept of Health and Human Services (1991) Healthy People 2000: National Health Promotion and Disease Prevention Objectives. Public Health Services.

US Dept of Health and Human Services (2000) Healthy People 2010: With Understanding and Improving Health Objectives for Improving Health, 2nd ed. US Dept of Health and Human Services, US Government Printing Office (Washington, DC).

(平成 14 年 6 月 20 日受付) 平成 15 年 3 月 27 日受理 